DOI: https://doi.org/10.15407/kvt202.04.057

UDC 517+519.2]:[57+61

ANTOMONOV M.Yu., DSc (Biology), Professor, Chief Researcher, the Department of Epidemiological Research and Medical Informatics, mail: antomonov@gmail.com

A.M. Marzeev Institute of Public Health of National Academy of Medical Sciences of Ukraine, 50, Popudrenko str., 02660, Kyiv, Ukraine

\title{
IMITATION OF COMPENSATOR AND ADAPTIVE PROCESSES IN BIOSYSTEMS
}

Introduction. The functioning efficiency of any biosystem (BS), regardless of its hierarchy level, depends on its adapt ability to changes in the environment or its state. Adaptive processes are implemented at the molecular, subcellular, cellular, tissue, organ, systemic and organismal levels. This adaptation can occur with the help of various mechanisms, has different dynamic characteristics, be accompanied by different energy costs and be more or less efficient. In this regard, it is expedient to identify as accurately as possible the type of adaptive process and assess its stressfulness for BS. In our opinion, such a classification can be carried out by formal markers of adaptive processes (by graphs) using mathematical methods of their description.

The purpose of the paper is to develop a formalized classification of adaptive processes types based on mathematical modeling of their dynamics.

Methods: structural and functional modeling using the approaches and mathematical apparatus of the theory of automatic control, using differential equations, probabilistic approaches and graphical analysis.

Results. The structurally functional model of the adaptive process is presented as three connected subsystems. The output process of the first subsystem is described by an exponential function with a constraint, of the second - a logistic (S-shaped) function, of the third their difference, i.e. unimodal curve. The operation of such a system is considered for different ratios of the parameters of the transfer functions of the subsystems (conversion factors and time constants). It is proposed to use the output function of this system as an identifier of various types of adaptive reactions: adaptation, compensation, reparative regeneration and a pathological process. Criteria for definition of such a distinction are proposed using integral and dynamic characteristics of mathematical models.

Conclusions. The proposed three-block diagram of the adaptive process makes it possible to perform its mathematical description in the simplest and most adequate form. Based on 
the paradigm of one-to-one correspondence of the structure and function of the adaptive process, it is possible to calculate the parameters of the subsystems involved in organizing the systemic response in response to external influences using the actually recorded graphs of thees adaptive processes: their conversion coefficients and time conctant. The systemic representation of the biosystem work gives us the probabilistically represent the participation process of the constituent subsystems when an external influence changes (evolutionary transformations). The developed criterion system allows, according to the graphs of the dynamics of the output function of a real biomedical research, to determine the type of adaptive process, that is, to correlate it with specific biological mechanisms and to assess the degree of its "pathology" for the biosystem.

Keywords: information technology, system approach, structural and functional modeling, approaches to the theory of automatic control, differential equations, probabilistic methods, graphic analysis.

\section{INTRODUCTION}

The functioning efficiency of any biosystem (BS), regardless of the level of the hierarchy, depends on its ability to adapt to changes in the environment or its state. Adaptive processes are implemented at the molecular, subcellular, cellular, tissue, organ, systemic and organismal levels. This adaptation can take place with the help of various mechanisms, have different dynamic characteristics, be accompanied by different energy costs and be more or less efficient.

In biomedical terminology, which is most fully represented in pathological physiology, the whole complex of adaptive reactions is called adaptive or compensatory-adaptive processes. The history of their formulation and clarification of differences in mechanisms lasts more than a century [1-4]. Currently, pathological physiology distinguishes some stages: activation of the biosystems functioning, relatively stable compensation and energy exhaustion (decompensation) [5]. Accordingly, in terms of severity (manifestation/ intensity), the processes are referred to as physiological adaptation, restorative (reparative) regeneration and pathological regeneration. Pathological manifestations can manifest themselves in various pathological processes: atrophy, hypertrophy, organization and rearrangement of tissues; metaplasia, etc. [6].

Consequently, based on the system concepts of the organization and functioning of the BS, we can say, that it is clear that processes can occur either with small changes, during which the BS "independently" adapts to the changed conditions of existence, or is forced to use mechanisms of interaction with other biosystems to use their resources in order to compensate for violations of its functioning.

In fact, we are talking about the distinction between relatively natural and acceptable for the body reactions from relatively "pathological" and much less acceptable for the body response to external influences. In this regard, it is obvious that it is expedient to identify the type of adaptive process as accurately as possible and assess its stressoriness for BS.

To our mind, such a classification can be performed according to the formal markers of the dynamics of adaptive processes using mathematical methods of their description.

The purpose of the paper is to develop a formalized classification of various types of adaptive processes in biosystems based on mathematical modeling of their dynamics. 


\section{RESEARCH METHODS}

As the main method for the formalized description of adaptive processes, we will use structural and functional modeling using the approaches and mathematical apparatus of the automatic regulation theory [7, 8].

In this case, we are guided by the basic postulate that any biological adaptive process can be characterized by a certain output function and a certain structure. Accordingly, its description can occur at the structural, functional or structural-functional level $[9,10,11]$.

As a rule, in the course of biosystem adaptive reactions, certain structural changes occur. The number of actively working subsystems changes, connections between them are broken or formed, redundant elements are connecting or overloaded (faulty) elements stop working etc. All these structural changes, of course, manifest themselves in a system output function change.

The mutual influence and connection between the structure and function of the system seems to be so rigid that it makes it possible to unambiguously link changes in the function of the system with changes in its structure. That is, an adaptive change in the structure entails a change in function, a change in function indicates a change in structure. Consequently, the structure of the BS within this approach can be judged by its function.

\section{STRUCTURAL AND FUNCTIONAL MODEL OF THE BIOSYSTEM ADAPTIVE RESPONSE TO EXTERNAL IMPACT}

Let us consider the simplest structural-functional model of the adaptive response of some BS in response to the action of some harmful environmental factor.

We will use the following assumptions.

1. Homeostatic functioning of any BS presupposes the existence of oppositely directed processes in it, capable of both increasing the values of the functioning indicators and decreasing them.

2. To organize an adaptive response in each BS, it is necessary to assume the presence of, at least, three subsystems that implement the mechanisms of perception, regulation and transmission of a signal outside the BS.

3 . The final adaptive response of the integral BS is the result of the interaction of these three subsystems.

Thus, the structure of the studied bioprocess should be presented in the form of, at least, three blocks. Moreover, the most adequate structure that meets the formulated conditions is the block diagram shown in Fig. 1.

In Fig. 1, the used notation is traditional for the theory of automatic control. Namely, $W$ is the transfer function (operator of transformation "input — output"), $p$ is Laplace operator $(p=d / d t)$. 


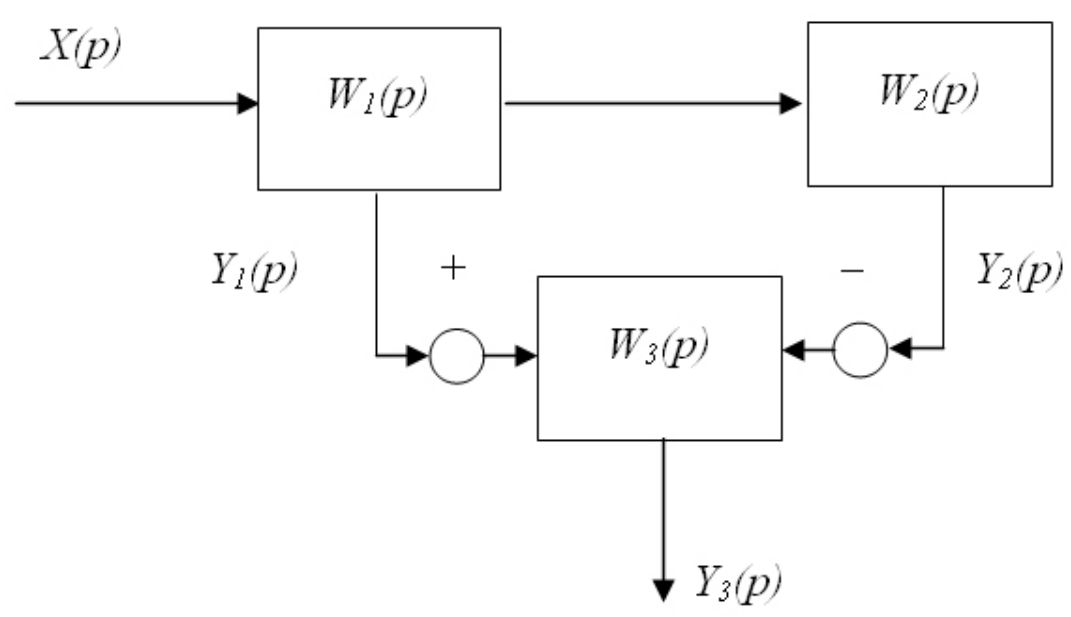

Fig. 1. Block diagram of a ring connection of three subsystems

Let us further assume that the first and second blocks are inertial links, and the third is just an adder with a certain transformation coefficient $k_{3}$, to which the signal from the first block arrives with the "+" sign, and from the second one — with the "-" sign. Then the transfer functions of these blocks will be written as follows:

$$
\begin{aligned}
& W_{1}(p)=\frac{Y_{1}(p)}{X(p)}=\left(\frac{k_{1}}{T_{1} p+1}\right), \\
& W_{2}(p)=\frac{Y_{2}(p)}{Y_{1}(p)}=\left(\frac{k_{2}}{T_{2} p+1}\right) ; \\
& W_{3}(p)=\frac{Y_{3}(p)}{Y_{1}(p)-Y_{2}(p)}=k_{3},
\end{aligned}
$$

where $k_{1}, k_{2}, k_{3}$ are conversion factors (amplification or attenuation) of signals arriving at the corresponding blocks, $T_{1}, T_{2}$ — time constants of the first two blocks.

Passing from the operator representation to the corresponding differential equations, we obtain the system:

$$
\begin{gathered}
T_{1} \frac{d y_{1}}{d t}+y_{1}=k_{1} x ; \\
T_{1} T_{2} \frac{d^{2} y_{2}}{d t^{2}}+\left(T_{1}+T_{2}\right) \frac{d y_{2}}{d t}+y_{2}=k_{1} k_{2} x ; \\
y_{3}=k_{3}\left(y_{1}-y_{2}\right),
\end{gathered}
$$

where $x$ denotes an input signal (action). 
The solution to the system of equations is the following functions:

$$
\begin{gathered}
y_{1}(t)=k_{1} x\left(1-e^{-\frac{t}{T_{1}}}\right) \\
y_{2}=k_{1} k_{2} x\left(1-\frac{T_{1}}{T_{1}-T_{2}} e^{-\frac{t}{T_{1}}}+\frac{T_{2}}{T_{1}-T_{2}} e^{-\frac{t}{T_{2}}}\right) .
\end{gathered}
$$

Therefore, the representation of the output function of the entire system will be written as follows:

$$
\begin{gathered}
y_{3}=k_{3} x\left[k_{1}\left(1-e^{-\frac{t}{T_{1}}}\right)-k_{1} k_{2}\left(1-\frac{T_{1}}{T_{1}-T_{2}} e^{-\frac{t}{T_{1}}}+\frac{T_{2}}{T_{1}-T_{2}} e^{-\frac{t}{T_{2}}}\right)\right]= \\
k_{1} k_{3} x\left[\left(1-k_{2}\right)+e^{-\frac{t}{T_{1}}}\left(\frac{T_{2}-T_{1}\left(1-k_{2}\right)}{T_{1}-T_{2}}\right)-e^{-\frac{t}{T_{2}}}\left(\frac{k_{2} T_{2}}{T_{1}-T_{2}}\right)\right] .
\end{gathered}
$$

Graphs of all three functions are shown in Fig. 2.

Let's consider in detail the functions of these subsystems (blocks).

The first block is under the influenced and plays a barrier protective role. In it, biotransformation (with a coefficient $k_{1}$ ) of the input signal $(x)$ takes place into a form adequate "for perception" by the entire system. Signal transmission into the biosystem occurs with some inertia (determined by the time constant $T_{1}$ ), which is a characteristic of any biological process. The coefficient of transmission (conversion) has a value determined by the strength of the action $(x)$ of the external signal and the capabilities of this subsystem. If the input signal is constant, the output function from this block is an exponent ( $y_{1}$ in Fig. 2) with an asymptote $k_{1} x$.

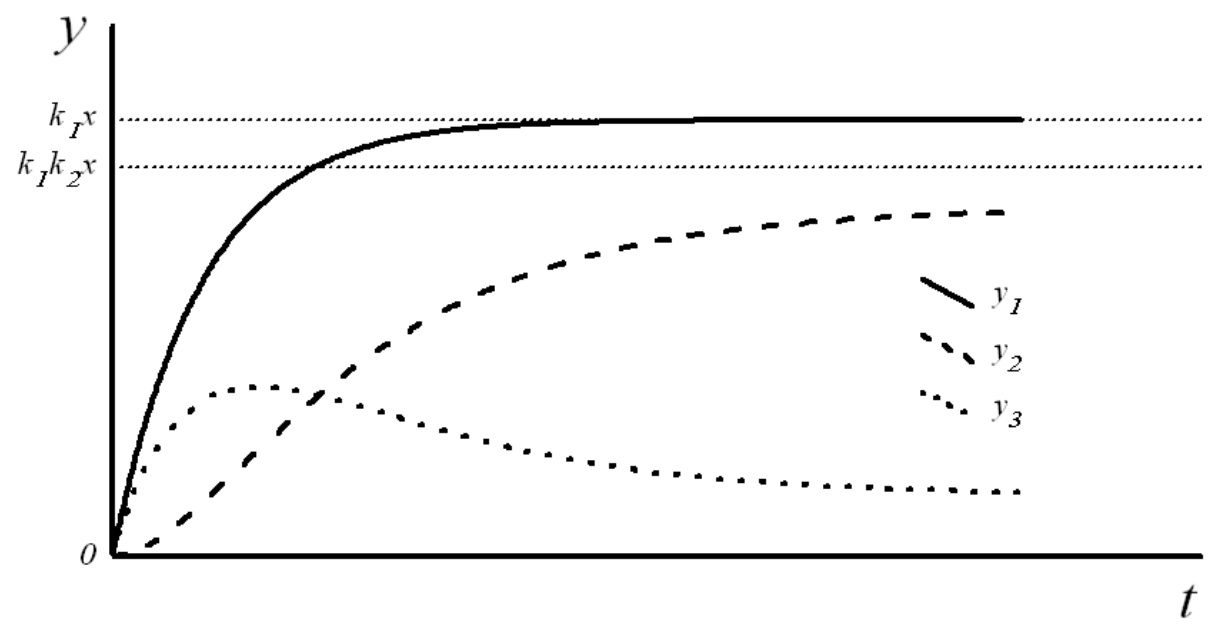

Fig. 2. Output functions of the three-block structure links 
Thus, since the input of the second block receives not a constant, but an exponentially increasing signal from the first block, the inertial processes of the second block lead to an even greater "pulling" of the signal ( $y_{2}$ in Fig. 2) and the transformation of its output function into an $S$-shaped form (logistic function) with an asymptote determined by the coefficients of both blocks and the influence force $\left(k_{1} k_{2} x\right)$.

At the third, output block, mutual analysis and comparison of signals from the first and second blocks takes place. Since they have different directions, they are subtracted in the third block. In addition, on this block, the signal is amplified (or attenuated) with a coefficient $k_{3}$ and is converted from codes "understandable" inside the BS to "outer codes".

All the regulatory mechanisms that implement the actual adaptive process are combined by us in the second subsystem (block). The impact indirectly coming on the third block through the first block seeks to bring its function beyond normal homeostatic oscillations. External influence reaches the second block also indirectly through the first block. In order for the second block to realize its adaptive task, the signal that is generated on it must come to the summing third block with a sign opposite to the signal from the first block. However, since second block signal lags behind the function of the first block, in the third block changes firstly develop until the opposition from the second block arrives.

If the signal gain in the second block is small compared to the gain of the first block $\left(k_{2}<k_{1}\right)$, this opposition can simply slow down the growth of the system output function or transfer it to a stable stationary phase ( $y_{1}$ in Fig. 3$)$.

If the gain on the second block is close to the gain on the first block, then the signal from the second block will inertially "extinguish" the first signal, and the deviations of the resulting function from the initial state begin to decrease until the system returns to initial state completely ( $y_{2}$ in Fig. 3 ).

If $k_{2}>k_{1}$, then the protective forces are "stronger" than the influence. The limiting stationary position of the output function can go into the negative halfplane, and changes in the function of the entire system will acquire a sign opposite to the initial changes ( $y_{3}$ in Fig. 3 ). All these curves can be considered typical expressions of the adaptive process.

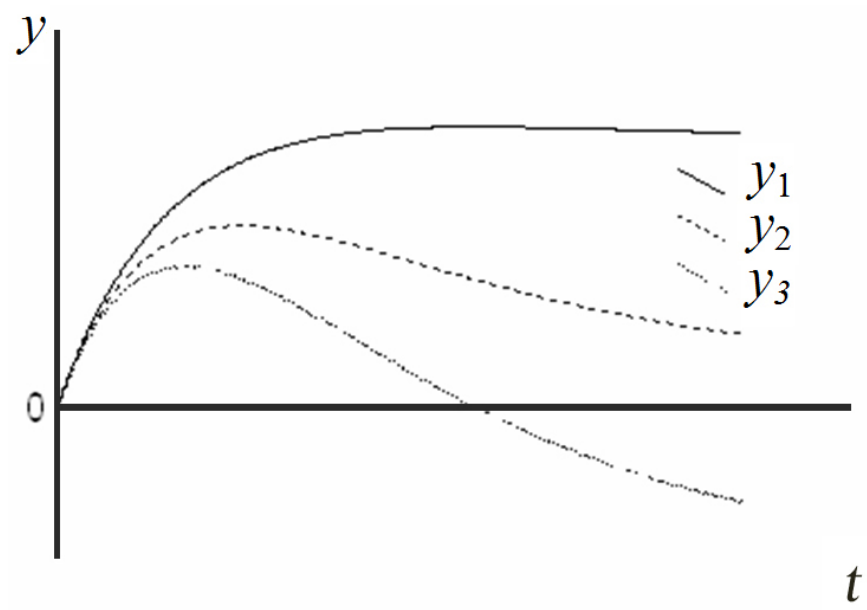

Fig. 3. Function of the adaptive process at different intensity of "resistance" to the influence: $y_{1}$ if $k_{2}<k_{1} ; y_{2}$ if $k_{2}={ }_{1} ; y_{3}$ if $k_{2}>k_{1}$ 
Or, on the contrary, proceeding from the paradigm of the structure and function relationship adopted by us, if an unimodal curve of the dynamics of the output function of the studied biosystem is observed in biomedical studies of adaptive processes, then it can be considered that this process decompose into two components: an exponential and an $S$-shaped function. Moreover, the exponential function reflects the negative changes initiated by the impact, and the $S$-shaped function has the opposite sign and characterizes the antagonistically directed compensatory-adaptive processes.

The corresponding structural and functional model of the process can be represented in the form of three blocks shown in Fig. 1.

Taking these provisions, one can admit the possibility of solving the so-called inverse problem. Namely, according to the initial data obtained as a result of a specific biomedical study and reflected in the form of an unimodal curve ( $\mathrm{y}_{3}$ in Fig. 2), it is possible to calculate the specific parameters of the output function. Since this function includes the parameters of all three blocks $\left(k_{1}, k_{2}, k_{3}, T_{1}, T_{2}\right)$, the characteristics of the constituent functions $\left(y_{1}\right.$ and $\left.y_{2}\right)$ can also be considered definite.

From them you can get information about the operation of the first and second subsystems, i.e. subsystems, information from which was not or could not recorded directly during the study. For example, you can calculate the time constants $T_{1}$ and $T_{2}$ and get information about the "persistence" of the corresponding subsystems.

By putting real biological prototypes in correspondence with all three blocks, it is possible to evaluate the qualitative and quantitative characteristics of biosystems involved in the formation of an adaptive response.

\section{PROBABILISTIC DYNAMIC MECHANISM OF ADAPTATION TO EXTERNAL IMPACT}

In the process of adaptation of the biosystem to changing external influences, they undergo successively a number of structural rearrangements. Each subsequent stage occurs, firstly, after the possibilities of the previous one begin to be exhausted, and, secondly, it is accompanied by large energy costs.

The probability or degree of participation of elements and subsystems in the work of a biosystem in the absence of impact can be characterized by a certain distribution function. Let us assume that this spatial distribution of subsystems obeys a normal law. Then the probability density curve of the participation of subsystems in the work of the biosystem (their activity) in the norm can be represented in the form of a bell of normal distribution (Fig. 4a).

The process of adaptation to the impact begins with the mobilization of those elements that, although they belong to the considered biosystem, but the probability of their participation in its work in a normal state (without impact) is rather small. As a result of the connection of these subsystems, the range of the biosystem reaction norm is expanded, its ability to function normally under changed external conditions increases.

The change in the nature of the distribution that occurs as a result of the backup subsystems connection is shown in Fig. 4b. The bell of the normal distribution gets wider, the variance increases. The biosystem becomes capable of functioning normally in a wider range of external conditions.

The next stage of adaptive rearrangements within a biosystem is characterized by the withdrawal from work of those elements whose work does not lead to facilitating the system functioning. Graphically, it is expressed by the appearance of some asymmetry in the distribution curve (Fig. 4c). 


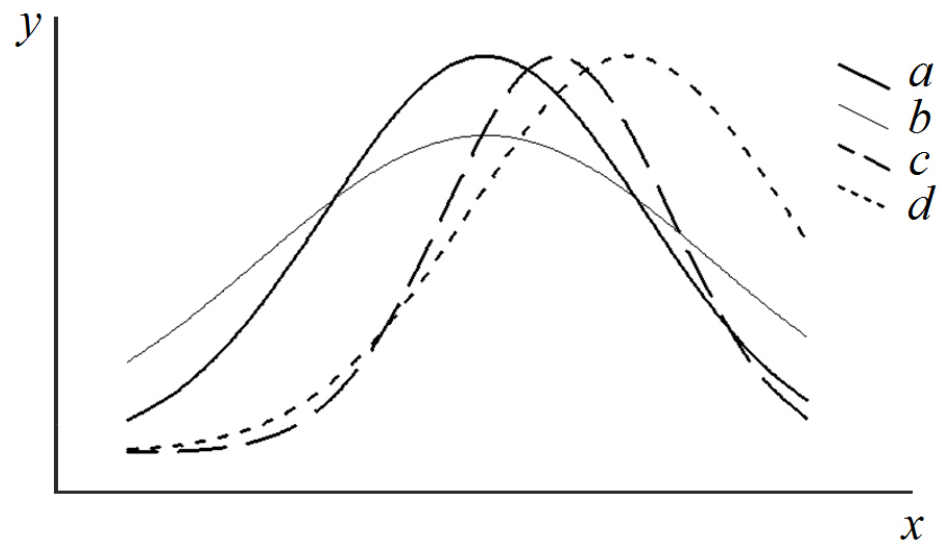

Fig. 4. Change in the distribution of the subsystems participation with an increase in external influence

A further change in the nature of the distribution with increasing influence, apparently, is expressed by the displacement of the distribution curve along the abscissa in the direction of increasing influence (Fig. 4d). Under the influence of the factor, there is a change in the use of certain subsystems by the biosystem. The greatest weight, the greatest probability of participation is acquired by those subsystems, the connection of which contributes to the normal functioning of the BS in the changed conditions. There is, as it was, a natural selection of the elements (subsystems) most beneficial for BS.

An example of such a structural reorganization taking place in real biosystems is intraorgan compensation of kidney nephrons in nephrosclerosis: nephrons that survived the destruction increase their function and hypertrophy. Similar structural and functional rearrangements occur after surgical removal of the upper half of the small intestine, when the secretion of the stomach and pancreas first increases (Fig. 4b), and then their compensatory hypertrophy develops (Fig. 4c).

\section{TYPES OF ADAPTIVE PROCESSES}

The nature of the BS's response to an external impact is determined both by the characteristics of the impact (the number and nature of the factors, their intensity, mode and duration of action) and the reaction of the biosystem itself (the number of subsystems reacting to this impact, their initial state, the specificity of the action of a factor or their combination on reacting systems etc.).

The term "adaptation" is often used as a synonym for adaptive responses in medicine and biology. Sometimes the concept of adaptation is identified with the concept of protection, accommodation, sensitization, resistance, evolutionary adaptability, functional mobility, changes in sensitivity etc.

If the possibility of the presence of different types of adaptive reactions is allowed (assumed), then the concept of "adaptation" in medicine and biology is often used as a synonym for the most "painless" adaptive process. In medicine, the concept of "decompensation" is used for processes that are "more pathological" in nature and are associated with a disease state. In toxicology in chronic intoxication, it is customary to distinguish between four stages of responsive adaptive processes occurring in the body, which successively replace one an- 
other with increasing exposure time: primary decompensation, physiological adaptation, compensated pathological process, decompensated pathology. In physiology, it is possible to differentiate adaptive processes into "norm", adaptation, compensation, reparative regeneration, "pathology".

However, no matter how many types of adaptive processes are divided and no matter how they are called, the criteria for their differentiation are very vague, rather subjective and do not have a quantitative expression.

In the further presentation, we will assume that the biosystem can react to the action of various factors with a whole range of adaptive reactions, of which at the moment it demonstrates only one. We will also assume that the following types of distinguishable and identifiable adaptive reactions are possible (in ascending order of the degree of damaging effect): 1) normal homeostatic changes, or simply "norm", 2) physiological adaptation, or simply "adaptation," 3) compensation, 4) repair (regeneration), 5) pathological (irreversible) changes, or simply "pathology".

\section{DEPENDENCE OF THE ADAPTIVE PROCESS TYPE ON THE BIOSYSTEMS HIERARCHY LEVEL}

Let us consider a hypothetical sequence of connecting hierarchically different structural formations in the implementation of an adaptive reaction. For simplicity, we will use only three levels of the hierarchy: BS - subsystem - element. It is natural to assume that with the same magnitude of the damaging effect, the degree of dysfunction of the system will be directly related to the level of its organization. So, with small influences, the elements function is first of all disrupted. With an increase in the active factor force, disturbances arise at the subsystems level, which, with a further increase in the factor influence, leads to disturbances in the functioning of the BS itself.

The intensity of the adaptive process directly depends on the impact level and is commensurate with the magnitude of the violations occurring. Therefore, at a constant magnitude of the impact, the lower the organization level of the reacting structure, the more pathological its adaptive reaction is, and vice versa, the higher the level of organization, the less manifestation of the reaction.

Table 1. Possible relationship between the type of adaptive process and the biosystem hierarchy level under various input influences

\begin{tabular}{c|c|c|c}
\hline \hline \multirow{2}{*}{$\begin{array}{c}\text { Impact intensity } \\
\text { (in convent. units) }\end{array}$} & Element & Subsystem & Biosystem \\
\cline { 2 - 4 } & norm & norm & norm \\
\hline \hline 0 & adaptation & norm & norm \\
\hline 1 & compensation & adaptation & norm \\
\hline 2 & pathology & compensation & adaptation \\
\hline 3 & death & pathology & compensation \\
\hline 3 & death & death & pathology \\
\hline 4 & death & death & death \\
\hline 5 & & &
\end{tabular}


Thus, the replacement of some elements by others in the course of the adaptive process is a process that is clearly compensatory in nature at the element level. However, at the subsystem level, this process can be characterized as adaptive. At the BS level, this change can manifest itself only in minor homeostatic fluctuations. Likewise, breakage of elements (i.e. their certain pathology) at the subsystems level can be regarded as a compensatory process, and at the level of the BS itself it can manifest itself as an insignificant adaptive deviation.

Consequently, we can assume that some correspondence of the hierarchy level of the system under consideration to the tension degree of the adaptive process taking place in it is fulfilled (Table 1).

This pattern reflects the evolutionarily developed relationship between the "security" of the system and the hierarchical level of its organization.

\section{FUNCTIONAL CLASSIFICATION OF ADAPTIVE PROCESSES}

As a rule, the experimental curves of the adaptive processes, subject to the obvious requirements for the experiments and their mathematical processing (selection of the body system most sensitive to this factor, the use of an integral indicator of system state, careful registration of the process etc.) with a sufficiently long exposure factors have the previously considered characteristic form of unimodal functions.

Let us consider an example of the introduction of formalized criteria according to the graphs "time/ effect" of the output functions of the BS $(y(t))$. As the main characteristics for distinguishing adaptive processes (adaptation, compensation, reparative regeneration and pathology), we will use the following indicators:

1) the ratio of the values of the function $y(t)$ with the limiting value of the reaction "norm" (the boundary of the "norm range" is $y_{0}(t)$ ),

2) the time of getting into the "norm range",

3 ) indicators of the "power" ("activity") of the process [12]. In this case, under the "norm range" we mean the range of homeostatic changes in the output function without external influence.

The consideration will be carried out for two periods of the study during the action of the factor $\left(t_{0}<t<t_{1}\right)$ and after the termination of its action (during the aftereffect $\left.\left(t>t_{1}\right)\right)$. In addition, for ease of classification, we will neglect the possible phasing of changes (the transition of the graph through the abscissa axis), and therefore we will consider these changes only in the positive half-plane.

By adaptation (physiological) we mean an adaptive process that is not accompanied by irreversible damage. That is, after a short-term deviation from the "extremely normal" value, the graph of the function returns to the "norm range" $\left(y<y_{0}\right)$ during the period of exposure. During the aftereffect $\left(t>t_{1}\right)$, the adaptation response does not differ from the control one, i.e. does not go beyond the boundaries of the " norm range " (Fig. 5).

The general view of the change in the BS output function during the compensatory process, in principle, can be of the same character as during adaptation. Under the action $\left(t_{0}<t<t_{1}\right)$, the output function leaves the "norm corridor" and returns to it until the action termination. During the aftereffect period $\left(t>t_{1}\right)$, the function does not differ from the control one. Therefore, the distinction between adaptation and compensation in such a functional description should be introduced not on a qualitative but on a quantitative level. 
For example, we can propose as a quantitative criterion a measure of the "intensity" ("activity") of the process $(S)$, which we will express through the area (integral) under the output function:

$$
S=\int_{t_{0}}^{t_{1}} y(t) d t,
$$

which indirectly reflects the expenses of biosystem energy resources.

Integral of the "norm range" value $y_{0}(t)$ :

$$
S_{0}=\int_{t_{0}}^{t_{1}} y_{0}(t) d t
$$

characterizes the "extremely normal" homeostatic energy expenditure.

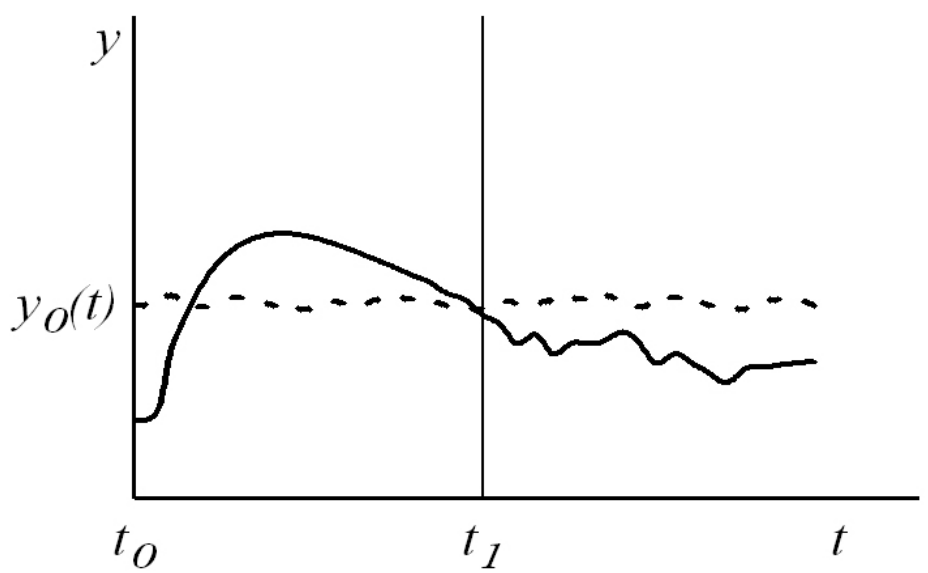

Fig. 5. Changes in the BS output function during the adaptation process

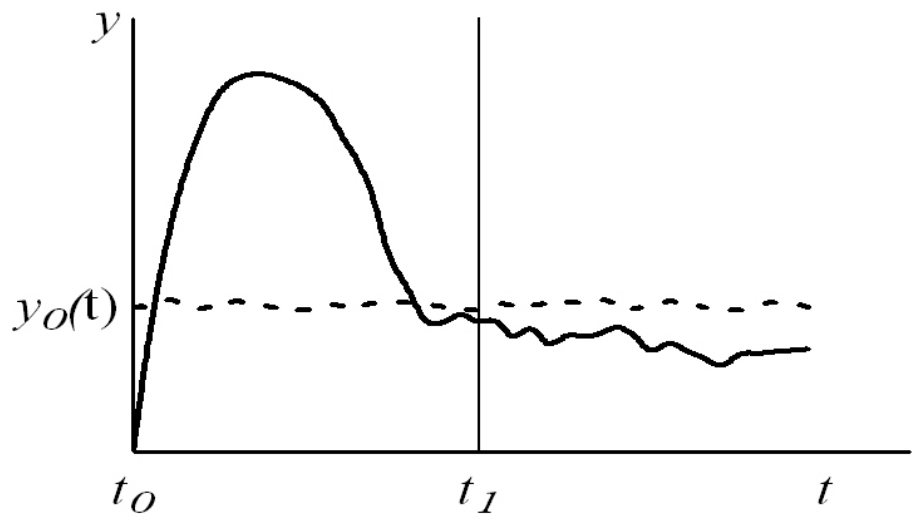

Fig. 6. Changes in the BS output function during the compensatory process 


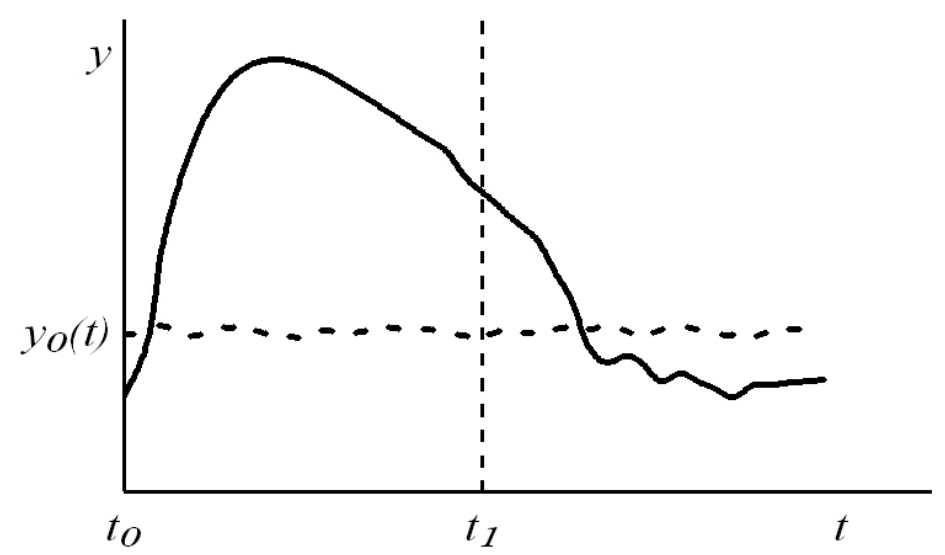

Fig. 7. Changes in the BS output function during reparative regeneration

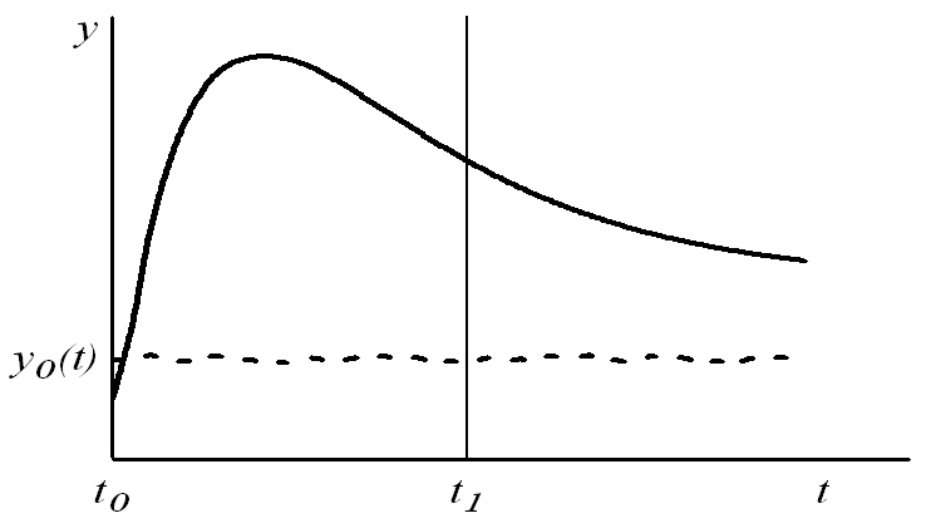

Fig. 8. Changes in the BS output function during the reaction "pathology"

If the value of the integral $S$ is less than the area of the "norm range", then the expenditure of resources of the biosystem is not excessive, if it is more, then such a waste of resources can lead to a certain pathology. Accordingly, at $S<S_{0}$, the response can be considered adaptive, at $S>S_{0}$ compensatory (Fig. 6).

The reparative regeneration reaction is an adaptive process of the next, "more pathological" level. Reparative regeneration is usually understand as a reaction in which changes in BS accumulated during the exposure period are eliminated during the recovery period. A possible graph of such dynamics is shown in Fig. 7.

During the exposure period, the function $y(t)$ leaves the "norm range" $y_{0}(t)$ and does not return to it during this entire period $\left(t_{0}<t<t_{1}\right)$. During restoration $\left(t>t_{1}\right)$, the function enters the "norm range": $y(t)<y_{0}(t)$.

With the reaction "pathology", the function $y(t)$, having left the "norm range" during the period of exposure, does not return to it even during the recovery period. One of the possible behavior types of such a function is shown in Fig. 8.

Thus, by the type of the DS output function, the adaptive process can be attributed to one type or another according to perfectly clear, easily recorded and quantitatively measured characteristics. 
The dependence of such a criterion distinction on two indicators is obvious: the exposure time and the boundaries of the "norm range". In our opinion, both of these dependencies are completely justified.

With a short exposure time, the process can be regarded as rather "pathological", but over a longer time interval, the same time changes can be attributed to a much less "dangerous" type of adaptive processes. There can be no adaptation "in general", but there can be adaptation under a certain mode of exposure, and by changing this mode, it is possible to obtain compensation or pathology from the initial adaptation.

The limits of the "norm" are determined by the methodological capabilities of the study, and the wider they are, the less reliable the assessment can be. For example, the same curve of the graph of the output function with a "narrow range " (an accurate method for assessing the "norm") can be reliably attributed to the adaptation or compensatory process, while with a "wide range " it may not go beyond its limits, and the process cannot be considered as going beyond the limits of normal homeostatic oscillations.

\section{WAVES OF PROBABILITY}

With a sequential change in the magnitude of the external influence, the onset probability of different adaptive reactions for the same BS will change. It is logical to assume that with an increase in the impact, the onset probability of the "less pathological" reactions will decrease, and the probability of the onset of "more pathological" reactions will increase.

Hypothetically, the distribution of the probability $(P)$ of the occurrence of different adaptive reactions, when the force of the external influence $(x)$ changes, can occur in Fig. 9.

The probability of reaction "norm" occurrence $\left(R_{n}\right)$, reflecting the BS normal state (Fig. 9a) is maximal at a certain value of the factor $x_{n}$ that is optimal for the organism (if the factor has only a "harmful" effect $x_{n}=0$ ). With a sequential increase (or decrease) of $\mathrm{x}$ relative to $\mathrm{xn}$, the probability of the "normal" reaction decreases, and the adaptation reaction probability $\left(P_{a}\right)$ becomes more and more probable, which at $x=x_{a}$ reaches a maximum (Fig. 9b).

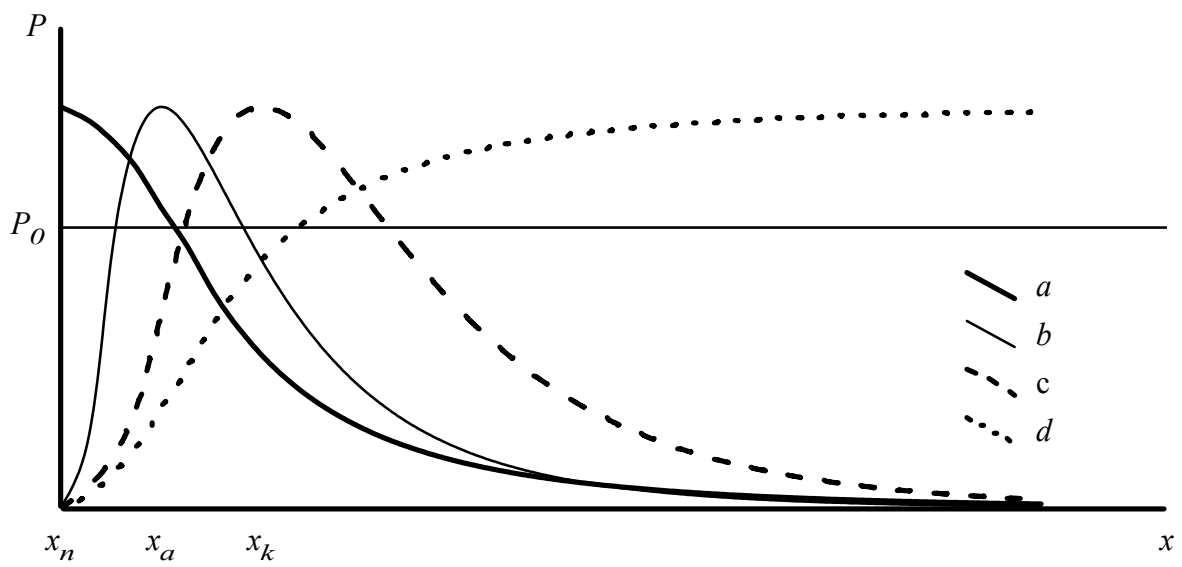

Fig. 9. Distribution of adaptive reactions when changing external influences 
With an increase in the factor at $x>x_{a}$, the probability of the occurrence of adaptation $P_{a}$ decreases, and a compensatory reaction $\left(P_{k}\right)$ becomes more probable. After the maximum strength of $P_{k}$ at $x=x_{k}$, the probability of a compensation reaction decreases. Similar processes occur with the probability of the reparative regeneration development. With an even greater increase in the level of exposure, this probability decreases, and the probability of irreversible pathological disorders $\left(P_{p}\right)$ increases.

The threshold $P_{0}$, with respect to which the probability of the adaptive processes occurrence are considered, is determined primarily by the method of detecting and differentiating the adaptive processes themselves. Its value has an essentially probabilistic nature. With a "good" method of differentiating processes, it is lower and "probability waves" have pronounced peaks. With a "bad" technique — the threshold is higher, and the "probability waves" themselves have more gentle maxima.

\section{CONCLUSIONS}

The proposed three-block diagram of the adaptive process allows us to present its structural and functional model in the simplest ("minimum necessary") form.

Based on the paradigm of one-to-one correspondence of the structure and function of the adaptive process, it is possible to calculate the parameters of the subsystems involved in organizing the systemic response using the actually recorded graphs of adaptive processes in response to external influences, namely their conversion coefficients and inertial properties.

The systemic representation of a biosystem functioning makes it possible to probabilistically represent the process of participation of the constituent subsystems when the external influence changes (evolutionary transformations).

The developed criterion system allows, according to the graphs of the output function dynamics of a real biomedical research, to determine the type of adaptive process, that is, to correlate it with specific biological mechanisms and to assess the degree of its "pathology" for the biosystem.

\section{REFERENCES}

1. Adaptation and compensation. The lancet, Volume 162, Issue 4188, 5 December 1903, Pages 1560-1566 https://doi.org/10.1016/S0140-6736(00)99549-7

2. Physiological Mechanisms and Adaptation Strategies in Plants Under Changing Environment (Parvaiz A., Mohd R. W.) v. 1 Springer 2013, 386 pp. DOI 10.1007 / 978-1-4614-8591-9.

3. Physiological Mechanisms and Adaptation Strategies in Plants Under Changing Environment (Parvaiz A., Mohd R. W.) v. 2 2014, 394 pp. DOI: 10.1007 / 978-1-4614-8600-8

4. Bronwyn J., Martin W. D. Adaptation, Compensation, and Decompensation. Normal and Abnormal Swallowing pp 77-84 Springer 2020, 235 pp.

5. Pathological anatomy: textbook / AI Strukov, VV Serov. -6th ed., Ster. M .: Litterra, 2015. 880 p. (in Russian)

6. Davydovsky I.V. General human pathology. - 2nd ed., Rev. and add. M: "Medicine", 1969. 612 p. (in Russian).

7. Marchenko, AA, Guliy, VS Nastenko DV Theory of automatic keruvannya. Pre-installation of automatic regulation systems. KPI im. Igor Sikorskogo, 2019, 31 p. (in Ukrainian)

8. Theory of automatic control: a textbook for universities. Lan, 2020, 219 p. (in Russian). 
9. Encyclopedia of Cybernetics: in 2 volumes / ed. V.M. Glushkova. Kiev: Goal. ed. Ukrainian Radianske Encyclopedia, 1973, 570 p. (in Ukrainian)

10. Antomonov M.Yu. Algorithmization of the choice of adequate mathematical methods in the analysis of biomedical data // Cybernetics and Computer Science. Kiev, 2007. Issue. 153. S. 12-23. (in Russian).

11. Antomonov M.Yu. Methodology for the formation of complex indicators in environmental and hygienic research. // Hygiene and Sanitation. 1993, N7. p. 20-22. (in Russian).

12. Antomonov M.Yu., Kozak LM Mathematical modeling of adaptation processes / Proceedings of the XIII International Scientific and Practical Conference "Adaptive Opportunities of Children and Youth" September 10-11, 2020, Odessa, pp.6-9. (in Ukrainian)

Received 04.08.2020

\section{ЛІТЕРАТУРА}

1. Adaptation and compensation. The lancet, Volume 162, Issue 4188, 5 December 1903, Pages 1560-1566 https://doi.org/10.1016/S0140-6736(00)99549-7

2. Physiological Mechanisms and Adaptation Strategies in Plants Under Changing Environment (Parvaiz A., Mohd R. W.) v.1 Springer 2013, 386 pp. DOI 10.1007/978-1-4614-8591-9.

3. Physiological Mechanisms and Adaptation Strategies in Plants Under Changing Environment (Parvaiz A., Mohd R. W.) v.2 2014, 394 pp. DOI: 10.1007/978-1-4614-8600-8

4. Bronwyn J., Martin W. D. Adaptation, Compensation, and Decompensation. Normal and Abnormal Swallowing pp 77-84 Springer 2020, 235 pp.

5. Патологическая анатомия: учебник / А. И. Струков, В. В. Серов. -6-е изд., стер. М.: Литтерра, 2015. 880 с.: ил.

6. Давыдовский И.В. Общая патология человека. - 2-е изд., перераб. и доп. - М: «Медицина», 1969. $612 \mathrm{c}$.

7. Марченко А.А., Гулий В.С., Настенко Д.В. Теорія автоматичного керування. Дослідження системи автоматичного регулювання. КПІ ім. Ігоря Сікорського, 2019 - 31 с.

8. Теория автоматического управления: учебное пособие для вузов. Лань, 2020, 219 с.

9. Енциклопедія кібернетики : у 2 т. / за ред. В. М. Глушкова. - Київ : Гол. ред. Української радянської енциклопедії, 1973, 570 с.

10. Антомонов М.Ю. Алгоритмизация выбора адекватных математических методов при анализе медико-биологических данных. Кибернетика и вычислительная техника. - Киев, 2007. - Вып. 153. - С. 12-23.

11. Антомонов М.Ю. Методика формирования комплексных показателей в экологогигиенических исследованиях. //Гигиена и санитария. 1993, N7. с.20-22.

12. Антомонов М.Ю., Козак Л.М. Математичне моделювання адаптаційних процесів / Збірник Наукових праць XIII міжнародной науково-практичной конференції «Адаптаційні можливості дітей та молоді», 10-11 вересня 2020 року, м. Одеса, с. 6-9.

Отримано 04.08.2020 
Антомонов М.Ю., д-р біол. наук, проф., головн. наук. співроб. лаб. епідеміологічних досліджень та медичної інформатики e-mail: antomonov@gmail.com ДУ «Інститут громадського здоров’я ім А.М. Марзєєва НАМН України», 50, вул. Попудренка, 02660, м. Київ, Україна

\section{МОДЕЛЛЮВАННЯ КОМПЕНСАТОРНО-ПРИСТОСУВАЛЬНИХ ПРОЦЕСІВ У БІОСИСТЕМАХ}

Вступ. Ефективність функціонування будь-якої біосистеми (БС), незалежно від рівня iii ієрархії, залежить від іiї здатності адаптуватися до змін навколишнього середовища або іiі стану. Адаптивні процеси реалізуються на молекулярному, субклітинному, клітинному, тканинному, органному, системному рівнях та рівні цілісного організму. Ця адаптація може відбуватися за допомогою різних механізмів, мати різні динамічні характеристики, супроводжуватися різними енергетичними витратами і бути більшменш ефективною. У зв'язку з цим доцільно якомога точніше визначити тип адаптаційного процесу та оцінити його стресогенність (патологічність) для БС. На наш погляд, таку класифікацію можна здійснювати формальними маркерами адаптивних процесів (за допомогою графіків) з використанням математичних методів їх опису.

Метою статті є розроблення формалізованої класифікації типів адаптивних процесів на основі математичного моделювання їхньої динаміки.

Методи: структурно-функціональне моделювання 3 використанням підходів та математичного апарату теорії автоматичного керування, з використанням диференціальних рівнянь, імовірнісних підходів та графічного аналізу.

Результати. Структурно-функціональну модель адаптивного процесу подано у вигляді трьох підсистем. Вихідний процес першої підсистеми описується експоненціальною функцією з обмеженням, другої - логістичною ( $S$-подібною) функцією, третьої їхньою різницею, тобто унімодальною кривою.

Роботу такої системи розглянуто для різних співвідношень параметрів передавальних функцій підсистем (коефіцієнтів перетворення та постійних часу). Вихідну функцію цієї системи запропоновано використовувати як ідентифікатор різних типів адаптаційних реакцій: адаптації, компенсації, репаративної регенерації та патологічного процесу. Встановлено критерії для визначення такого розділення 3 використанням інтегральних та динамічних характеристик математичних моделей.

Висновки. Запропонована трьохблочна схема адаптивного процесу дає змогу виконати його математичний опис у найпростішій та найадекватнішій формі. Виходячи 3 парадигми взаємозалежності структури та функції адаптивного процесу, можна розрахувати параметри підсистем, які беруть участь в організації системної реакції у відповідь на зовнішні впливи, використовуючи фактично записані графіки цих адаптивних процесів: їхні коефіцієнти перетворення та постійні часу. Системне подання функціонування біосистеми дає нам імовірнісне уявлення про процес участі складників підсистем, коли зовнішній вплив змінюється (еволюційні перетворення). Розроблена система критеріїв дає змогу за графіками динаміки вихідної функції реального біомедичного дослідження визначити тип адаптаційного процесу, тобто зіставити його з конкретними біологічними механізмами та оцінити ступінь його "патології" для біосистеми.

Ключові слова: інформаційні технології, системний підхід, структурно-функціональне моделювання, підходи до теорії автоматичного керування, диференціальні рівняння, імовірнісні методи, графічний аналіз. 